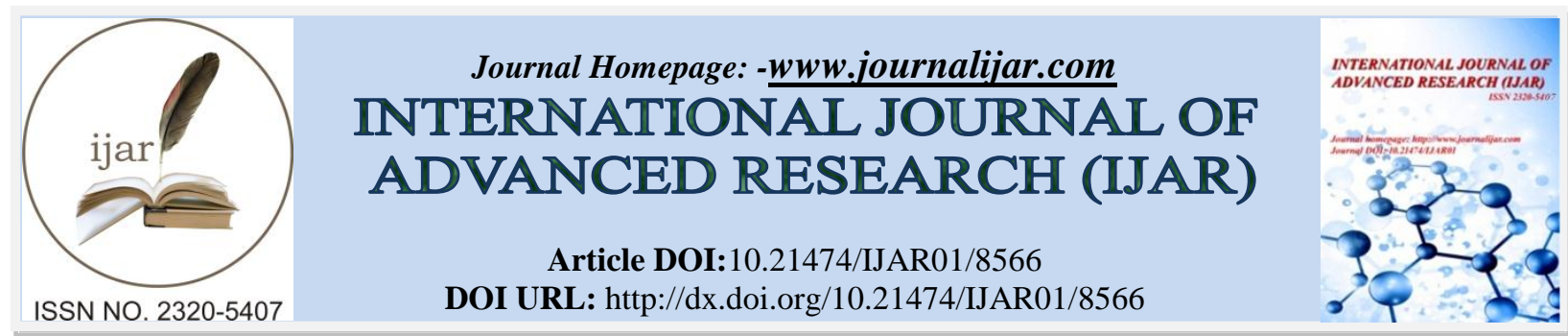

RESEARCH ARTICLE

\title{
ENGLISH COMMUNICATION INSTRUCTIONAL MODEL TO ENHANCE LISTENING-SPEAKING ABILITIES OF POLICE STUDENTS AT POLICE PROVINCIAL TRAINING CENTER REGION 7.
}

\section{Kritaya Sukprasert ${ }^{1}$, Sa-ngiam Torut ${ }^{2}$, Bamrung Torut ${ }^{2}$ and Pranee Ninlakorn ${ }^{2}$.}

1. Ph.D .Candidate in Curriculum and Instruction, Faculty of Education, Silpakorn University, Thailand.

2. Thesis advisors, Faculty of Education, Silpakorn University, Thailand.

\section{Manuscript Info}

\section{Manuscript History}

Received: 14 December 2018

Final Accepted: 16 January 2019

Published: February 2019

\section{Key words:-}

English communication instructional model, Listening-speaking abilities, Police students, Police Provincial Training Center Region 7.

\begin{abstract}
The purposes of this research were: 1) to study the necessity of English listening-speaking skills of police students at Police Provincial Training Center Region 7; 2) to develop an English communication instructional model to meet the efficiency criteria of 80/80;3) to compare listeningspeaking abilities of police students before and after given an English communication instructional model and its effect size; and 4) to survey police students' opinion towards the English communication instructional model. The researcher indicated the sample size with purposive sampling, retrieving 30 police students, who have been selected for admission to the Police Cadet Course of the fiscal year 2017. The research tools were 10 lessons and teaching material in accordance with the English communication instructional model. Data was analyzed by Mean, Standard Deviation, Effect size, and Dependent t-test. The results of this research were as follow: the students' needs identified by the self-assessment questionnaires showed that student needs on content, language use and benefits were appropriate for practical situations. The efficiency score of an English communication instructional model was $78.77 / 80.67$, which was at the acceptable level based on the criterion stated. The listening-speaking abilities after using an English communication instructional model were significantly higher at the level of 0.05 ; and its effect size was very large at level of 5.37. The students' opinions toward the English communication instructional model were at high level.
\end{abstract}

Copy Right, IJAR, 2019,. All rights reserved.

\section{Introduction:-}

English language nowadays has been developed as an international language which takes the most roles in the age of borderless communication; it is also important for education in the $21^{\text {st }}$ century. Among the language skills, listening skills are very essential to human because it is an important basis to develop other skills (Oxford, 1993). Initially, the student must have the ability to listen because when they understand what they have listened, it will affect the development of speaking, reading and writing skills. The English speaking skills are important to learn English language because these skills represent the level of ability to learn English; and they can be also the indicator of the ability to use foreign languages (Richards, 2001).

Corresponding Author:-Kritaya Sukprasert.

Address:-Ph.D .Candidate in Curriculum and Instruction, Faculty of Education, Silpakorn University, Thailand. 
Thailand is the member of ASEAN which English is used as the international language for communication. At present, there are still problems about English language teaching. Regarding listening skills, it is found that many Thai students have studied English language for many years but they cannot communicate in English efficiently. Regarding speaking skills, it is found that students lack opportunity to use English, thus they lack confidence in speaking English because they do not have experience. In addition, Thai people do not like to practice because they are afraid of being wrong. Johnson \& Morrow (1981) presented the principle of English language for communication teaching that the instructor must inform students about the objective of studying and practicing language in order to make language learning meaningful to them' and they will realize that they can do more things after studying. The teaching in the integration style is to combine various skills; sometimes this might require actions from students to do activities in a manner that is like using real-life language. The instructor should also organize various activities for students to have more opportunity to use language, and to not be afraid of being wrong. The instructor must initially focus on the fluency of using language without having to fix the mistakes of the students every time. This is to grant language usage rather than language methods (Richards and Rodgers, 2001; Littlewood, 1995; Williams, 1994). It can be seen that to organize the communication activities is important to language studying; it is the opportunity for the students to practice their language skills; it motivates students to study language; it is the natural way to study language by really using language for communication; and it also create good interaction between instructor and students. The instructor should also create good atmosphere to support each student to try to study language (Littlewood, 1981). The instructors must teach the students to practice language skills as much as possible in order that students can use language as a tool for communicating with others as they wish in various situations both in classroom and in their daily life. One of the methods to help students really use language in their daily life is the communicative language teaching (CLT) (Ministry of Education, 2015).

Royal Thai Police have determined the learning of English for communication in the education program of police cadets under the Education Division, by using the training course of Provincial Police Region 6 as the common course. However, the training course only focuses on reading and writing skills, but it lacks the practice of listening and speaking skills by performing the role-play in various simulated situations. Therefore, the English teaching to help students use English for communication is very important due to the duties of police officers, which are to issue visa for people entering - exiting the country, to provide convenience and assistance to foreigners living in the country, to maintain the peace and order, to prevent and suppress crime and suspend cases, and to manage the traffic accident.

From the mentioned above, it is necessary for the police officers to strengthen their knowledge of English for communication about listening-speaking abilities and the language duty to enhance efficiency, to create more knowledge about working of the police profession, to provide service to people in basic with gracefulness and reliability to create faith from both Thai and foreign people.

\section{Purposes of research:-}

1. To study the necessity of English listening-speaking skills of police students at Police Provincial Training Center Region 7.

2. To develop an English communication instructional model to meet the efficiency criteria of 80/80.

3. To compare listening-speaking abilities of police students before and after given an English communication instructional model and its effect size.

4. To survey police students' opinion towards the English communication instructional model.

\section{Hypotheses of research:-}

1. The English communication instructional model to enhance listening-speaking abilities of police students at Police Provincial Training Center Region 7, created by the researcher, has efficiency according to the criteria $80 / 80$.

2. The listening-speaking abilities, after using the English communication instructional model to enhance listening-speaking abilities of police students at Police Provincial Training Center Region 7, is higher than before using the English communication instructional model, and the effect must be in big size.

3. The opinion of police students at Police Provincial Training Center Region 7 towards the English communication instructional model to enhance listening-speaking abilities of police students at Police Provincial Training Center Region 7 is at high level. 


\section{Literature Review:- \\ English listening comprehension:-}

English listening comprehension is a complex process which requires skills about linguistic units, including linguistic skills and intellectual skills, strategy and expectation of the listener to be used in translating the topic and situations presented. The language comprehension is concerned about 2 kinds of knowledge: linguistic knowledge and non-linguistic knowledge. The linguistic knowledge that is important for listening is the knowledge about sound, vocabulary, grammar, meaning, and text structure; while the non-linguistic knowledge consists of knowledge about topic, context and general knowledge (Richards, Platt \& Platt, 1992; Buck, 2001).

Finocchiaro\&Bonomo (1973) presented that the components of foreign language listening comprehension rely on the listener's familiarity to words, expectation of words to hear in that situation, redundant clues of language, and the ability to remember messages being heard. Rivers (1980) pointed out that listening had 3 components; 1) linguistic information, 2) situation context, and 3) comprehended message. In addition, Wipf (1984) described the components of listening: sound discrimination, grammatical structures, vocabulary, stress and intonation, and rhythm of speaking. Moreover, Nicholas (1988) said that the components of the foreign language listening comprehension are 1) linguistic competence, 2) knowledge of the world, and 3) familiarity with the subject of discussion.

Rost (1991) said that to be successful in listening, the listeners should have these 3 skills; 1) perception skills, 2 ) analysis skills, and 3) synthesis skills. The listening is to integrate these 3 skills: when listening, the listener can distinguish the sound and remember the words, can classify grammatical units and meaningful expressions or words, and also can connect the language to other indicators in order to use the same knowledge for listening comprehension. Besides, Richards (1987) presented the characteristics of listening activities as follows; 1) matching, 2) transferring, 3) transcribing, 4) scanning, 5) extending, 6) condensing, 7) answering, and 8) predicting.

\section{English speaking:-}

The speaking for communication is the behavior type that involve 2 people or more, speaker and listener. The speaker must transmit the message in appropriate language spoken, stress and intonation, including the expression through face and action. These help express the meaning of what is said, with the purpose of allowing listeners to understand and interpret correctly (Scott, 1981; Finocchiaro\&Brumfit, 1983; Celce-Murcia \&Olshtain, 2000).

Bachman (1990) presented 2 components of speaking; language knowledge and strategic competence. Heaton (1990) summarized that the components of speaking are about pronunciation, grammar and structure, intonation and pauses, vocabulary, and meaning. Moreover, Weir (1993) said that the ability of speaking consist of 1) fluency of language use, 2) appropriateness of language selection and politeness, 3) grammatical and structural accuracy, and 4) range and variety of vocabulary and complexity of language spoken.

Harris (1988) mentioned the speaking skills which consist of the abilities as follows; 1) pronunciation, 2) grammar, 3) vocabulary, 4) fluency, and 5) comprehensibility. In addition, Valette\&Disick (1972) distinguished the speaking behavior into 5 levels; 1) the level of mechanical skill in which students can mimic the sound, 2) the level of knowledge in which students can use the meaning of the language that is memorized, 3) the level of transfer in which students can use the grammatical rules that they have learnt to create new sentences, 4) the level of communication in which students can express their opinion and need to others freely, and 5) the level of criticism in which students can interpret, apply their understanding, and convey the meaning. Furthermore, Carrol (1980) classify the level of ability to speak into 9 levels; 1) non-speaker, 2) intermittent speaker, 3) extremely limited speaker, 4) marginal speaker, 5) modest speaker, 6) competent speaker, 7) good speaker, 8) very good non-native speaker, and 9) expert speaker.

Regarding the speaking teaching activities, the instructor has to stimulate students to really use their language knowledge, which requires rehearsal, feedback, and to motivate students to be interested in and to engage in speaking. There are 3 steps to teach the speaking skills; introduction of new knowledge, language training, and communication activities, such as to use problem solving activities, to perform role-playing, or to use simulations (Harmer, 1992). Moreover, Lazaraton (2001) presented 6 activities to develop the speaking skills of English as a second language student, which are 1) discussion, 2) speaking, 3) role-play, 4) conversation, 5) conversation recording, and 6) other activities: short conversation, structured interview. 


\section{Teaching listening - speaking English for communication:-}

The present teaching method of language for communication becomes broadly popular, thus English language instructor needs to have knowledge and understanding about activities for communication because this is an important key helping the instructor to be able to teach English to enable students to communicate. Richards \& Rodgers (2001) said that the teaching for communication in one of the theories in teaching a language that begins to teach communication in a given language form until being able to actually use the language. The instructor has to search for the teaching methods and teaching materials for each activity in classroom appropriately. The communicative approach is an ability to use language correctly and appropriately when exchanging or contacting with others in the society. The students know when and how to say, what to say, say to whom, where to say, and say in what manner. The meaning of this communication ability makes teaching methods for communication have a lot of role in the teaching and learning of English nowadays (Hybel, 1995).

According to Nunan (2004), the teaching of language for communication can be divided into 2 types; 1) strong interpretation of communicative language teaching: the instructor will look at the process of learning the second language of the students as the process of learning the first language of people who learn language from everyday language use (Natural Communication), and 2) weak interpretation of communicative language teaching: the instructor will propose principles, rules, norms of language for students to understand the relationship between cause and effect of grammatical principles use before applying. Language teaching requires class activities that are conducive to this learning process by organizing activities that motivate students, give opportunities to express opinions and identity of students; this has relationships or importance to students (Littlewood, 1989).

Richards (2006) also suggested 2 more process-oriented approaches of teaching for communication; 1) contentbased approach: this focuses on learning content to be integrated with the language teaching goals, and 2) taskbased approach: this is the language studying from the interaction, which has 4 goals; (1) to use English language to communicate and perform the assigned tasks successfully, (2) to apply the language knowledge and experience, that has been received, in real life, (3) to develop thinking skills through the work operation, and (4) to behave properly in working with others.

The measurement and evaluation of English language teaching is important because it is the teaching activity that the instructor must measure and evaluate in accordance with the learning objectives. Valette (1977) suggested about the listening test as follows; 1) skimming, 2) oral comprehension, 3) perception, 4) transfer the oral message, and 5) dictation.

\section{Development of teaching styles:-}

Richards (1987) presented the listening activities as follows; data transfer, note taking, finding information, providing information, summaries, answering questions, forecasting, and matching. The outstanding points of the listening teaching activities of Richards are the presentation of various activities so that the instructor can start at any steps, without the need to sort and can develop the teaching at any stage to be more efficient and effective by using 2 types of assessment; formative evaluation and summative evaluation. In addition, Byrne (1990) presented 3 steps of organizing the activities for speaking teaching; 1 ) content presentation process is a step that the instructor must provide language knowledge, 2) the training process is a step that the instructor plans to allow the student to practice using the initial knowledge in a fluent manner, and 3) the process of using the language is a step by which the instructor allows student to use language knowledge to communicate meaningfully.

Stufflebeam \& Shinkfield (2007) presented the direction of CIPP evaluation model which is to evaluate the overall of model, the application of model. The evaluator can access the data for measuring and improving the curriculum, the usage of resource, time, and technology efficiently in 4 aspects; involving and serving stakeholders, improvement orientation, objectivist orientation, and standards and Meta evaluation.

The determination of teaching activities is synthesized the teaching steps from the concepts of Harmer (1992) and Torut (2006) (see table 1). 
Table 1:-Teaching steps from the concepts of Harmer (1992) and Torut (2006)

\begin{tabular}{|l|l|l|}
\hline \multicolumn{1}{|c|}{ Harmer (1992) } & \multicolumn{1}{|c|}{ Torut (2006) } & \multicolumn{1}{c|}{ Summary } \\
\hline Steps of speaking for & Steps of activity for communication & Teaching stepsare divided into 7 \\
steps, as follow; \\
1. Reaching a Consensus & 1. Lead in & 1. Lead in \\
2. Relaying Instruction & 1.2 Linguistic background knowledge & 2. Pre-listening task \\
3. Communicative Game & 2. Input & 2.1 Vocabulary \\
3.1 Find the Differences & 3. Teacher's direct comprehension through & 2.2 Guided question \\
3.2 Describe and Arrange & extensive questions & 3. Listening comprehension task \\
Pictures & 4. Students' tasks on intensive questions & 4. Language study related to speaking \\
3.3 Story Reconstruction & 5. Language focus needed for post & with \\
4. Problem-Solving & reading/listening and extended activities & 4.1 Noticing \\
5. Interpersonal Exchange & 6. Post reading/listening tasks & 4.2 Generalizing rules \\
6. Simulation & 6.1 Extended activities localization/ & 4.3 Practicing \\
& personalization cooperation & 5. Communicative activities in given \\
& 6.1.1 Portfolio collection & situation -Role play \\
& 6.2 Self-study/study library skills & 6. Evaluation \\
\end{tabular}

\section{Scope of Research:-}

1. Population and sample: the population of this research is police students at Police Provincial Training Center Region 7, which is divided into 2 phases;

Phase 1:

The population of this research is police students who have been selected for admission to the Police Cadet Course of the fiscal year 2016, under Police Provincial Training Center Region 7, totaling 2 companies, 200 police students (Education Services Department, Police Provincial Training Center Region 7). The researcher determined the sample size with purposive sampling, retrieving 40 police students who were on duty and were in the same company so that the data retrieved from the questionnaire can be used to study the necessity of English learning of the police profession.

\section{Phase 2:-}

The population of this research is police students who have been selected for admission to the Police Cadet Course of the fiscal year 2017, under Police Provincial Training Center Region 7, totaling 4 companies, 490 police students (Education Services Department, Police Provincial Training Center Region 7). The researcher determined the sample size with purposive sampling, retrieving 30 police students from $3^{\text {rd }}$ company due to the reason that this company studied English language as the first class, as category 1, subcategory 1-3, as their schedule of training and duty at the same time.

The variables of this research were; 1) controlled variable was the English communication instructional model to enhance listening-speaking abilities of police students at Police Provincial Training Center Region 7, and 2) the independent variable were the ability of English speaking-listening and opinion towards the English communication instructional model of police students at Police Provincial Training Center Region 7.

\section{Research Tool:-}

1. Self-assessment questionnaire

2. 10 lessons and teaching materials in accordance with the English communication instructional model

3. Pre-test and post-test of English listening - speaking ability

4. Questionnaire of students' opinions on teaching styles in 5 point rating scale

The tools used in the research were examined for content validity and reliability by using the Index of Item Objective Congruence (IOC) from the evaluation of 3 experts in order to ensure the quality and appropriateness of tools before being really used. 


\section{Research Methodology:-}

This study is the research and development with the pre-experimental research by using the one group pretestposttest design. The methodology is divided into 3 phases, as follows;

Phase 1: Analysis of basic information on the necessity for studying the English listening-speaking in work of police.

The researcher studied the necessity for studying and development of listening-speaking ability and the ability about language functions related to police work, by conducting the interview with the experts in the curriculum and answering the self-assessment form from 40 police officers.

Phase 2: Designing the teaching styles, developing the teaching assessment tools, and experimenting to find the effectiveness of teaching model to meet the criteria.

The researcher used the results of the study of basic information about the police students in Phase 1 to be used as a guideline for designing and developing the English communication instructional model to enhance listeningspeaking abilities of police students, which its steps are as follows;

\section{Step 1:-}

1. Designing the English communication instructional model in order to determine the unit specifications for 10 lessons, as follows;

2. Determine the study objectives by using the information in Phase 1 to set the main goal for developing the listening-speaking ability.

3. Define the content by using the information in Phase 1 to determine the learning details that are relevant to the operation of police.

4. Determine the learning process,implementing the teaching process in accordance with the concepts of Harmer (1992) and Torut (2006) in 8 steps;

5. The step of lead-in aims to give students an idea of the overall picture of what they will study before taking the next step in the next lesson.

6. The step of pre-listening comprehension starts at teaching vocabulary and posing the guided questions so that students can study the meaning of the vocabulary that will appear in the conversation; thus they understand the meaning and need to know what happens in that lesson.

7. The step of listening comprehension is the activity of conversation to practice listening skills in the situation that is consistent with the lesson and summarizes the situation that occurs in listening to their own words.

8. The step of language study related to the listening text and useful for speaking practice aims at students to understand the listening and to be the guidelines for creating conversation in next activity.

9. The step of communicative activities in given situations, in which students perform role-play in the situations determined.

10. The steps of extended activities as part-time activities by using internet to encourage greater understanding.

11. The step of wrap-up is the self-evaluation from studying record for that lesson.

12. The step of lesson quiz; the listening quiz can be in the form of answering question, while the speaking quiz can be the role-play.

13. The determination of the studying evaluation was divided into 2 parts; 1 ) formative evaluation: all points will be used to determine the efficiency of teaching styles according to criteria 80 (E1), and 2) Summative evaluation: the test is the same as those which were used in the pre-test and post-test (E2), the point will be used to determine the efficiency of teaching styles according to criteria 80/80.

14. The questionnaire to survey the opinion of police students towards the English communication instructional model in the form of 5 point rating scale. The question is concerned about 1) listening - speaking, 2) management of listening-speaking teaching activities, 3) measure and evaluation, and 4) the benefits.

15. Checking the quality and efficiency of teaching models by presenting the research tools, lesson documents and teaching materials, listening-speaking ability test, and questionnaire, to the advisor and 3 experts to test the content validity. The results of IOC in between $0.5-1$. In addition, the researcher took the ability test in the part of 80 multiple choice exams to find the quality of the exam, by allowing 30 police sergeants to test the exam to find the item difficulty (p) and the item discrimination ( $r$ ), and found that the test is in the period of $0.2-0.8$, which means the test is appropriate. 


\section{Step 2:-}

The application of teaching model to pilot study in order to develop the teaching model to be in accordance with the criteria $80 / 80$ by testing with 3 police students to find and correct the errors of lessons before using the model to teach 10 police students in small group. The results of pilot study show that the efficiency of teaching model E1/E2 was 78.60/80.07, which means the efficiency of teaching model is appropriate to be used to experiment with police students in real sample groups.

\section{Phase 3:-}

The use of developed teaching model and the evaluation of the use of developed teaching model.

\section{Research Results:-}

The researcher presented the results of using the English communication instructional model to enhance listeningspeaking abilities of police students at Police Provincial Training Center Region 7 in accordance with the purposes of research, as follows;

With regard to the necessity of studying English language for communication, in the aspects of content, language usage, and benefits, the results show that it was appropriate to be operated in the real situation.

With regard to the development of the English communication instructional model to enhance listening-speaking abilities of police students at Police Provincial Training Center Region 7, the results show that the efficiency criteria E1/E2 result was 78.77/80.67, which means it was accepted according to the specified criteria. It is also relevant to the set hypothesis.

The effectiveness of English communication instructional model was as follows:-

The comparison results of listening-speaking abilities before and after given an English communication instructional model and its effect size.

With regard to the comparison results of listening-speaking abilities before and after given an English communication instructional model, the results show that the mean of post-test score of listening-speaking abilities of 30 police students as the samplewas 80.67, while the pre-test score was 53.00. Therefore, the difference of mean score between pre-test and post-test was 27.67. The t-test results was 29.43; which shows that the listening-speaking abilities of 30 police studentsafter studying the English communication instructional model was higher than the abilities before studying with the statistical significance at level of .05 . The effect size was 5.37, which means the effect was very big (see table 2).

Table 2:- Mean, standard deviation, and t-test of the comparison results of listening-speaking abilities before and after given an English communication instructional model and its effect size

\begin{tabular}{|c|c|c|c|c|c|c|c|c|c|}
\hline Test & $\begin{array}{c}\text { Full } \\
\text { score }\end{array}$ & $\begin{array}{c}\text { Mean } \\
(\overline{\mathrm{x}})\end{array}$ & $\begin{array}{c}\text { Standard } \\
\text { deviation(SD) }\end{array}$ & $\begin{array}{c}\text { Difference } \\
\text { between means } \\
(\mathbf{d})\end{array}$ & $\begin{array}{c}\text { Standard } \\
\text { deviation of } \\
\text { difference } \\
\text { (SD) }\end{array}$ & $\mathbf{t}$ & df & $\begin{array}{c}\text { effect } \\
\text { size }\end{array}$ & $\begin{array}{c}\text { Sig. } \\
\text { (2-tailed) }\end{array}$ \\
\hline Pre-test & 100 & 53.00 & 5.84 & 27.67 & 5.15 & $29.43^{*}$ & 29 & 5.37 & 0.00 \\
\hline Post-test & 100 & 80.67 & 2.97 & 29 & & \\
\hline
\end{tabular}

*the statistical significance at level of .05

With regard to the opinion of police students at Police Provincial Training Center Region 7 towards the English communication instructional model, created by the researcher, the results show that in total, the mean was 4.45 and the standard deviation was 0.70; it can be concluded that police students sample had the opinion towards the English communication instructional model at high level. In particular, benefit had the highest mean score $(\overline{\mathrm{x}}=4.54$, S.D. $=0.50)$, followed by measure and evaluation $(\bar{x}=4.27$, S.D. $=0.66)$, content $(\bar{x}=4.08$, S.D. $=0.72)$, teaching management in listening activities $(\overline{\mathrm{x}}=3.97$, S.D. $=0.73)$, and teaching management in speaking activities $(\overline{\mathrm{x}}=3.96$, S.D. $=0.73)$ respectively. 


\section{Discussion:-}

The results of the development of the English communication instructional model to enhance listening-speaking abilities of police students at Police Provincial Training Center Region 7 can be discussed as follows;

The necessity of English listening-speaking skills for police students at Police Provincial Training Center Region 7

Regarding the listening skills, the results show that the police students need to strengthen their knowledge about listening for understanding, to be prepared about the vocabulary andsound separation, to memorize vocabularies and words that convey the meaning of words. This is relevant to the study of Meksutas (2005), who studied the development of English supplementary listening exercises based on local topics by measuring the text listening skills then finding its headings and telling its details. The results show that listening to the conversation and telling the events that happened in the past, listening to the conversation and identifying locations, listening to messages and identifying causes and consequences, listening to the conversation and identifying how to use that thing, listening to the conversation and distinguishing career groups, listening to the conversation and telling steps in performing various activities, and listening to the conversation and telling the sequence of events

Regarding the speaking skills, the results show that to develop the speaking skills was not as difficult as expected because the student has listened to the story as a guideline, and the instructor has provided the language guide that will be used in speaking step-by-step; starting from having education issues on language, idioms, and vocabulary to be used in conversation. This is relevant to the study of Tipmontree (2007), who studied the Use and the problems of English and intercultural communication skills of Thai tourist police officers, and found that tourist police had problems about grammar and understanding with foreigner's accent, also the problem to understand the foreign tourists and to reply to them. Moreover, the most common problems with the foreign tourists were losing their belongings, being robbed, and fighting with local people. In case that tourist police cannot communicate to them, they will use body language, eye contact, facial expression in communication. There were also problems about the proper use of distance and paralanguage. These were the important problems caused by the inability to understand the accent of foreign tourists, to understand what they want, and to reply to them.

With regard to the results of the development of English communication instructional model to enhance listeningspeaking abilities of police students at Police Provincial Training Center Region 7, the results show that the efficiency criteria E1/E2 result was in accordance with the specified criteria 80/80. This is relevant to the study of Meksutas (2005), who studied the development of English Supplementary listening exercises based on local topics for eighth grade students of Tessaban 2 WatPrasattong School, SuphanBuri, and found that the efficiency criteria E1/E2 result of practice form to enhance English listening skills according to the local curriculum was 76.29/78.08, which means it was at good level. Moreover, it is also relevant to the study of Pumarin (2005), who studied about the development of English language training courses for the performance of tourist police officers under the Tourist Police Division, and found that the efficiency criteria E1/E2 result of English language training courses was in accordance with the specified criteria 80/80. The development of the English communication instructional model to enhance listening-speaking abilities of police students at Police Provincial Training Center Region 7 by the researcher was in accordance with the development of all processes of media from studying the needs of students, defining the learning context, arranging lesson material to meet the workload. The teaching management had the process to enhance the listening-speaking, by that before listening, the researcher recognized informing the basic guidelines for listening by explaining the background and language content in form of teaching the relevant vocabularies and posing the question guidelines so that students can catch the meaning while listening and understand easily. The researcher measured the comprehension of sub-skills from the listening message, then encourage students to develop what they listen to their speaking through the role-play. At the end, the police students were allowed to do the self-evaluation by filling in the details of what they have learned in each lesson. The details of each activity were as follows;

Regarding the listening activities, due to the reason that the listening activities consist of presenting the vocabularies and picture using the technic of jigsaw, and questions as guidelines in order to help develop listening comprehension skills. In addition, after listening, examine the understanding from listening by letting students summarize the content of what has been listened. Therefore, the listening activities were not boring; the students will see the value of listening comprehension. There were few problems because the content in the activities was interesting with illustrations. This is relevant to the study of Park (2004), who studied the effect of the visual description section for listening comprehension of Korean students studying foreign languages, by studying how Korean students listen to understand English by using a virtual speech editing in the video as an experiment tool.It is divided into 3 groups: 
the above average, the average, and the under average. Then, study by letting them watch the editing of 6 sets of videos with different headings. It was found that all 3 groups of students were able to score the best under experiment of full topic, followed by a partial topic, and without topic respectively. Therefore, the use of partial internal explanations was as effective as having a full description, only in groups of students learning English as a foreign language, who were more advanced than other groups.

Regarding the speaking activities, there was the simulated situation which was as similar to the real one as possible to let students perform their role-play with the situation that was explicit, simple, with the language example as the practice guideline. The simulated situation was in accordance with the lesson and the responsible duty of police profession. Therefore, the police students see the value of studying English for communication and applying the knowledge in their work after finishing the training. This is relevant to the study of Chuenchom (2011), who studied the development of English listening and speaking skills of MathayomSuksa 4 Students at NawamaRachanusorn School by using role-playing, and found that students who were taught by using role-playing had higher listeningspeaking skills than before studying with the statistical significance at .01. In addition, this is relevant to the study of Ponglangka (2007), who studied using role-playing activities to develop English speaking ability of Mathayom five students, and found that the ability to speak English for communication by using role-playing activities of students higher than before the experiment with statistical significance at .01 .

The comparison results of listening-speaking abilities of police students were that the mean of post-test was higher than the mean of pre-test with statistical significance at .05. This is relevant to the study of Puensaen (2011), who studied the development of skills in the use of English for tourism police, and found that after receiving the training; the tourist police had higher English proficiency skills scores than before training. Moreover, this is relevant to the study of Chomchuen et al. (2011), who studied the development of an English manual for traffic police in Bangkok, and found that between before and after the training, the traffic polices had different English abilities with statistical significance at .05 ; by that the abilities of traffic polices after training was higher than before training.

Regarding the opinion of police students at Police Provincial Training Center Region 7 towards the English communication instructional model, the results show that the police students sample had the opinion towards the English communication instructional model at high level. In particular, benefit had the highest mean score, followed by measure and evaluation, content, teaching management in listening activities, and teaching management in speaking activities respectively. This is relevant to the study of Siribun et al. (2005), who studied production of English language training sets for tourist police at KoSamui District, SuratThani Province, and found that the opinion towards English language training sets in total was that it was appropriate. In addition, this is relevant to the study of Pumarin (2005) which found that trainees had higher English language knowledge and skills scores after training than before training with statistical significance at .01 .

\section{Recommendations for this Research:-}

The researcher presented recommendations for applying the English communication instructional model efficiently, as follows;

1. The size of group for role-play should consist of 4-5 people so that the police students can take their role in carrying out their work according to the role they receive in order to improve the social skills of the police students.

2. The police students should be encouraged to use the learning resources outside the classroom to allow them to study from various kinds of media, to enhance their own learning experience by studying the English conversation sample to understand the meaning of vocabulary used in the police profession. In addition, the police students have the opportunity to practice speaking skills along with studying in the classroom.

\section{Recommendations for Future Research:-}

1. The researcher presented the recommendations for future research, as follows;

2. Regarding the research designfor this research, the researcher indicated the testing plan with a group of police students by doing the pre-test and post-test, using the same tool for comparing the results from the teaching model. Therefore, researchers who are interested in furthering this research, should conduct the research with different research design, for example, the research design with 2 sample groups or more, which are the experimental group, the controlled group or the comparing group, in order to compare the results from the teaching model, or to compare the group of police students with different ability to find the difference in the English listening-speaking ability between the better group and weaker group, after using the English communication instructional model. 
3. The lesson should be developed to cover 4 skills: listening, speaking, reading, and writing.

4. Due to the reason that the basic knowledge about language of the police students is different, the overall teaching management might have problems for students with different basic knowledge. Therefore, there should be the research to encourage the self-study via online media in terms of vocabulary about police profession, exponents of expressions in various situations, or the important use of language for communication.

5. In order to communicate naturally, the agencies responsible of Thai Royal Police should study the results of the use of English for communication for the police officers by conducting the research along with using the online media to allow them to study by themselves.

\section{References:-}

1. Bachman, L. F. (1990). Fundamental Considerations in Language Testing. Oxford: Oxford University.

2. Buck, G. (2001). Assessing Listening. Cambridge: Cambridge University.

3. Byrne, D. (1990). Process VS Content. In English Teaching in Perspectives. London: Longman.

4. Carroll, B. J. (1980). Testing Communicative Performance. Oxford: Pergamon.

5. Celce-Murcia, M. and Olstain, E. (2000). Discourse and Context in Language Teaching. Cambridge: Cambridge University.

6. Chomchuen, K. et al. (2011). The development of an English manual for traffic police in Bangkok. Faculty of Humanities and Social Science, SuanDusitRajabhat University.

7. Chuenchom, P. (2011). The development of English listening and speaking skills of Mathayom Suksa 4 Students at NawamaRachanusorn School by using role-playing, Thesis of Master of Education, Dhonburi Rajabhat University.

8. Finocchiaro, M. and Bonomo, M. (1973). The Foreign Language Learners: A Guide for Teachers. New York: Regents Publishing.

9. Finocchiaro, M. and Brumfit, C. (1983). The Functional-Notional Approach from Theory to Practice. Oxford: Oxford University.

10. Harmer, J. (1992). The Practice of English Language Teaching. London: Longman.

11. Harris, D. P. (1988). Testing English as a Second Language. New York: McGraw-Hill.

12. Heaton, J. B. (1990). Classroom testing: Testing Speaking Skills. London: Longman.

13. Hybel, S. (1995). Communicating Effective Approach. New York: McGraw-Hill.

14. Johnson, K. andMorrow, K. (1981). Communication in the Classroom: Application and Mathods for a Communicative Approach. London: Longman.

15. Lazaraton, A. (2001). Teaching oral skill. In M. Celce-Murcia (Ed.) Teaching English as a Second or Foreign Language $\left(3^{\text {rd }}\right.$ ed.). Boston: Heinle\&Heinle.

16. Littlewood, W. (1981). Communicative Language Teaching. Cambridge: Cambridge University.

17. Littlewood, W. (1989). Foreign and Second Language Learning: Language Acquisition Research and its Implications for the Classroom. Cambridge: Cambridge University.

18. Littlewood, W. (1995). Communicative Language Teaching. Cambridge: Cambridge University.

19. Meksutas, S. (2005). The development of English Supplementary listening exercises based on local topics for eighth grade students of Tessaban 2 WatPrasattong School, SuphanBuri. Thesis of Master of Education, Silpakorn University.

20. Ministry of Education. (2013). New English language teaching and learning management manual according to the European language proficiency reference framework: secondary level. Bangkok: English Language Institute, Office of the Basic Education Commission.

21. Nicholas, L. N. (1988). Teaching Listening Comprehension. English Teaching Forum, 26, 19-22.

22. Nunan, D. (2004). Task-based Language Teaching. Cambridge: Cambridge University.

23. Oxford, R. L. (1993). Research update on teaching L2 listening. System, 21: 205-211.

24. Park, C. (2004). The Graduate Teaching Assistant (GTA): Lessons from North American Experience. Teaching in Higher Education, 9(3), 349-361.

25. Ponglangka, K. (2007). The study of using role-playing activities to develop English speaking ability of Mathayom five students, Independent Study of Master of Arts, Srinakharinwirot University.

26. Puensaen, W. (2011). The development of skills in the use of English for tourism police in Khonkaen province, Independent study of Master of Public Administration, Khonkaen University.

27. Pumarin, S. (2005). The development of English language training courses for the performance of tourist police officers under the Tourist Police Division. Thesis of Master of Education, PhranakhonRajabhat University.

28. Richards, J. (1987). Listening comprehension: Approach, design, procedure. In M.H. Long \& J.C. Richards (Eds.), Methodology in TESOL—A book of readings. New York: Newbury House. 
29. Richards, J. C. (2001). Curriculum Development in Language Teaching. Cambridge: Cambridge University Press.

30. Richards, J. C. (2006). Communicative Language Teaching Today. Singapore: Cambridge University.

31. Richards, J. C., Platt, J., and Platt, H. (1992). Longman Dictionary of Language Teaching \& Applied Linguistics. UK: Longman Group.

32. Richards, J. C. and Rodgers, T. (2001). Approaches and Methods in Language Teaching ( $2^{\text {nd }}$ ed.). Cambridge University.

33. Rivers, W. M. (1980). English Teaching Foreign Language Skills. Chicago: The University of Chicago.

34. Rost, M. (1991). Listening in Action. New Jersey: Prentice-Hall.

35. Scott, R. (1981). Speaking" in Communication in the Classroom (ed.). Keith Jonson and Keith Morrow, London: Longman.

36. Siribun et al. (2005). Production of English language training sets for tourist police at Ko Samui District, SuratThani Province. Independent Study of Master of Arts, Naresuan University.

37. Stufflebeam, D. L., \& Shinkfield, A. J. (2007). Evaluation Theory, Models and Applications. San Francisco, CA: Jossey-Bass.

38. Tipmontree, S. (2007). The Use and the problems of English and intercultural communication skills of Thai tourist police officers. Thesis, University of the Thai Chamber of Commerce.

39. Torut, S. (2006). The Development of EFL Supplementary Materials for Thai learners. Journal of Education, Silpakorn University. 3, 2(March), 51-75.

40. Valette, R. M. (1977). Modern Language Testing. New York: Harcourt Brace Jovanovich.

41. Valette, R. M. and Disick, R. S. (1972). Modern Language Performance Objectives and Individualizations. New York: Harcourt Brace Jovanovich.

42. Weir, C. J. (1993). Understanding \& Developing Language Tests. Englewood Cliffs: Prentice-Hall.

43. Williams, E. (1994). Reading in the Language Classroom ( $8^{\text {th }}$ ed.). London: MacMillan.

44. Wipf, J. (1984). Strategies for Teaching Second Language Listening Comprehension. Foreign Language Annals, 17. 